\title{
ВПЛИВ АМБІВАЛЕНТНОСТІ НА ПРОЦЕС ПРИЙНЯТТЯ РІШЕННЯ КОМАНДИРОМ: ФІЛОСОФСЬКО-ПСИХОЛОГІЧНИЙ АСПЕКТ
}

\begin{abstract}
У статті представлено сучасні підходи до філософсько-психологічного бачення амбівалентності та проведено аналіз ї̈ впливу на прийняття рішення командиром в умовах невизначеності.

Ключові слова: амбівалентність; невизначеність; прийняття рішення; командир.

В статье представлено современные подходы философско-психологического видения амбивалентности а такэне проведен анализ ее воздействия на принятия решения командиром в условиях неопределенности.

Ключевые слова: амбивалентность; неопределенность; принятие решения; командир.
\end{abstract}

Актуальність дослідження. В умовах сьогодення, українській армії як ніколи потрібні командири здатні нестандартно i швидко мислити та приймати правильні рішення у ситуації невизначеності, чітко діяти при вирішенні складних бойових завдань. Значною мірою на результат прийняття рішення впливає почугтя амбівалентності.

$$
\text { Ситуація невизначеності й }
$$
амбівалентність $є$ невід'ємними (взаємокорелюючими) атрибугами особистості командира при прийнятті рішення. При повній невизначеності напруга амбівалентності максимально зростає i майже «паралізує» людину у прийнятті нею рішення. В такій ситуації людина не здатна прийняти рішення, відмовляючись від будь-яких дій. I лише зі зміною ситуації, або в ситуації часткової невизначеності, особистість здатна до прийняття певних рішень.

Роль і значення феномену амбівалентності у людському суспільстві науковці відмічають досить давно. Разом 3 тим, сучасна наука визнає, що сутність амбівалентності не вивчено до сьогодні, незважаючи на значну кількість досліджень у цьому напрямі.

Аналіз останніх досліджень і публікацій. У новому філософському словникові поняття амбівалентність трактується як наявність у людини протилежних емоцій, бажань по відношенню до одного і того ж об'єкта (любов та ненависть, симпатія і антипатія і т.п.).

Нині цей термін часто використовується й за межами психології (зокрема в філософіiі) в більш широкому сенсі, коли мова йде про протиріччя, невизначеність, неоднозначність тієї чи іншої дії, оцінки, установки.

Проблемою прийняття рішення в умовах невизначеності займаються психологи Т. Корнілова, Д. Канеман, А. Тверські, О. Хайрулін. У вітчизняних i зарубіжних психологічних джерелах

проблемі амбівалентності присвячені праці К. Абрахама, Д. Віннікотта, Т. Зелінської, М. Клейн, Т. Лук'яненко, 3. Фройда, А. Хурчак, Т. Чуйко. У XXI столітті внесок у розвиток уявлень про амбівалентність внесли Ф. Гиренок, П. Зима, М. Корецька, Н. Котова, Ю. Крістева, А. Лобанова, Т. Ойзерман, К. Островська, С. К. Цвітухіна, Є. Шапінська і В. Шапінський, завдяки роботам яких можна простежити становлення феномена амбівалентності в його філософському контексті.

Мета дослідження. Актуалізувати проблему прийняття рішення командиром в умовах невизначеності, ознайомити 3 філософсько-психологічними аспектами амбівалентності та іiі впливу на прийняття рішення в умовах невизначеності.

Методи дослідження. Оглядовоаналітичне дослідження літератури.

Виклад основного матеріалу.

Сучасне життя військовика - це безкінечне прийняття рішень в умовах невизначеності. В умовах війни, безпосередньо перевіряючись боєм, рішення командира постає як серцевина всієі мисленевої ланки людини [6]. I якщо для одних командирів це $є$ можливістю показати свою творчу лідерську натуру, подолати обмеження і відкритися чомусь новому, то для іншої половини командирів це додатковий виклик, який ускладнює процес прийняття рішення. Для багатьох командирів невизначеність $є$ вагомою проблемою, особливо якщо вони відчувають сильну потребу в безпеці, відчувають себе комфортно лише в тій ситуації, де вони впевнені, бояться змін або не впевнені, що впораються з наслідками прийнятого рішення та не в змозі нести за нього відповідальність. Саме ситуація невизначеності породжує напругу амбівалентності особистості 


\section{Питання психології}

командира при прийнятті ним рішення [7]. Що ж це за феномен амбівалентності?

Філософське розуміння амбівалентності як відображення в людській свідомості суперечливих процесів і протилежних сил в універсумі грунтується на принципах дуалізму, плюралізму, причинності, полярності, універсальності. Саме життя - це вічні добро і зло, успіх i поразка, любов i ненависть, народження і смерть тощо (М. Бердяєв, А. Камю, Ф. Ніцше) [2].

В рамках антропології знаходиться потреба людини розкрити таємницю своєї природи, осмислити себе з позиції філософії людини і виявити своє справжнє існування. Однак при цьому науковим співтовариством ігнорується вагома для бугтя людини обумовленість - амбівалентність його бугтя, в якій, як ми припускаємо, знаходиться ключ до його розгадки.

Витоки філософської лінії обмірковування амбівалентності $€$ архаїчними.

Античні мислителі розглядали амбівалентність як систему бінарних відносин. Так, у Платона, творця учіння про душу, в основу були покладені онтологічні, гносеологічні а також етичні питання такі як турбота про душу в контексті співвідношення душі та тіла, проблеми задоволення та страждання, смертності людини і безсмертя іiі душі. Він розрізняв в душі, а також в державі три початки: пожадливе, пристрасне і розумне та висунув ідею внутрішнього конфлікту між ними, а також гармонії всіх початків під керівництвом розуму як основи внугрішньо особистісної і внугрішньо державної гармонії.

У Арістотеля рушійною силою поведінки вважається прагнення, яке виражається внутрішньою активністю організму і поєднане 3 почуттям задоволення і незадоволення. Те, що робиться нами самими, але всупереч нашому ж бажанню і доказам розуму, він називає насильницьким [5].

Марк Аврелій вважає, що йому доводиться спілкуватися 3 людьми нав'язливими, невдячними, підступними через те, що вони всі не пізнали природу добра та зла. Пізнавши, природу добра та зла, ти перестаєш гніватися на людей та ненавидіти їх [5].

В епоху Середньовіччя, відроджуючи античну традицію, широкий інтерес до складної i суперечливої структури буття i людини особливо проявляли А.Августин i П.Абеляр.

Зокрема, досягненням Августина стало висвітлення проблеми реальної динаміки конкретного людського життя на протилежність конкретній історії суспільства. Він стверджує дуалізм душі та тіла зазначивши, що розум $\epsilon$ повністю присугній сам в собі, тобто знає точно власну субстанцію або натуру. У праці «Про Град Божий», Августин визнає існування двох видів людської спільноти: «Град Земний», тобто державність, яка заснована на «самозакоханості, доведеній до зневажання Бога», i «Град Божий»- духовна спільність, заснована на «любові до Бога, доведеній до зневаги самого себе».

П'єр Абеляр раціоналізує відносини віри і розуму, вважаючи обов'язковою умовою віри розуміння («розумію, щоб вірити»). Початковими принципами критики П'єром Абеляром авторитетів церкви виступають сумніви у безумовній істинності положень віри i теза про необхідність осмисленого відношення до священних текстів (оскільки «богослови часто вчать того, чого самі не розуміють»). Відповідно до концепції «двох істин», П'єр Абеляр вважав, що в компетенцію віри входять думки про невидимі речі, які не доступні людським відчуттям і розташовані за межами реального світу. Безумовність авторитету Священного Писання в рішенні спірних питань не виключає можливість i навіть необхідність існування іншого способу досягнення істини, який П'єр Абеляр бачить у діалектиці. Слова можуть мати безліч значень, тому можлива контекстуальна двозначність, яка зумовлює $\mathrm{i}$ внутрішню суперечність християнських текстів, які вимагають аналізу їхньої мови за допомогою діалектики.

$\mathrm{y}$ Новий час Р. Декарт, розвиваючи конщепцію дуалізму, доклав чимало зусиль для дослідження неоднорідної структури людини, у котрої буття поділене на мислячу (дух) та протяжну (матерію) субстанції. У людині ці субстанції співіснують незалежно одна від одної (так званий психофізичний паралелізм). У свой роботі «Пристрасті душі», автор зазначає, що наше добро як і наше зло залежать головним чином від внутрішніх хвилювань, які викликаються в душі нею ж самою. I хоча ці хвилювання душі часто пов'язані 3 пристрастями, які мають 3 ними схожість, вони часто можуть зустрічатися i 3 іншими пристрастями i навіть виникати iз протилежних їм пристрастей. Декарт зазначає, що коли ми читаємо про надзвичайні пригоди чи бачимо їх на сцені, це може визвати в нас смуток, радість, любов або ненависть і взагалі будь-які емоції в залежності від того, які предмети представляє наша уява. Але ми разом 3 тим відчуваємо задоволення від збудженого у 


\section{Питання психології}

нас відчуття, і це задоволення $є$ інтелектуальна радість, що народжується із суму точно так як i з всіх інших пристрастей [5].

В класичній філософії І. Кант і Г.В.Ф. Гегель, розробляючи онтологічну i гносеологічну сторону своїх учінь, експлікують висновки, що стосуються антиномічності і діалектичності буття, і на людину. Так, кантівська трансцендентальна діалектика полягає в тому, що будь-яка надмірна трансцендентність, будь-який рух, який витісняє самовладання розуму, випливає 3 його іманентної структури, як спокуса, що виникає з глибини самої свідомості. А Гегель зауважує, що загальне обіймає в собі i одиничне, і особливе, а одиничне $\epsilon$, разом 3 тим, загальність в самому собі. Кожне 3 перерахованих понять в трактуванні протиріччя правомірно, але лише в рамках онтології або гносеології, оскільки кожне 3 них ігнорує все різноманіття проявів людини в світі, в той час як бугтя людини приховує в собі цю визначальну особливість - його причетність до буття, що обумовлює характер сугності людини і іï причетність до світу, тим самим зумовлюючи характер іiі існування [10].

Найяскравішим прикладом некласичної філософії слугує філософія Ф. Ніцше, яка передбачає подолання фальшивості бугтя шляхом збереження в ньому феномена амбівалентності. Некласичне мислення, що зародилося в філософії Ф. Ніцше, та сприйняте усією подальшою філософією, розкриває екзистенціально-есенціальну обумовленість людини, робить феномен амбівалентності ключем до бугтя людини, в якому людину рухають як екзистенційні, так і ессенціальні потяги в своїх почугтях, рішеннях, ідеях. Філософія життя Ф. Ніцше бачить людину як амбівалентність. Це означає не зняття ключових для бугтя людини протиріч, а визнання i збереження їх в свободі i різноманітності. Головний стрижень протиріччя концепції $Ф$. Ніцше амбівалентність ідеї «надлюдини» і «вічного повернення». 3 точки зору раціональності ці ідеї подекуди виключають одна одну, їх синтез неможливий, а співіснування - абсурдно. У феномені амбівалентності ж вони співіснують як імпульси збереження i розвитку, виступаючи символічним аналогом амбівалентного відношення есенції i екзистенції, сугності та існування відповідно.

Змістом своєї філософії Ф. Ніцше показав безпосередність і природність амбівалентного прочитання людини. Він «вивільнив» попередню філософію, яка прагне протиставити і нівелювати або один, або інший елемент 3 бугтя людини: екзистенцію у випадку з ідеалістичної філософією, есенцію у випадку 3 матеріалістичної філософією. Зокрема він зазначав, що вміння зносити протиріччя $\epsilon$ ознакою високої культури. Тому $\Phi$. Ніцше не можна віднести до філософів жодного з цих відомих напрямків, він по праву - філософ життя, яке ні есенціальне, ні екзистенційне, а амбівалентне. Цей досвід переоцінки традиційних принципів мислення, який повернувся подальшим визнанням продуктивності амбівалентного некласичного дискурсу, також зробив величезний вплив на сучасність. Філософія життя Ф. Ніцше розглядає феномен амбівалентності як можливість здійснення вільного самовизначення людини в сучасному світі. Людина обумовлена двома силами: своєю сугністю i своїм існуванням, есенцією i екзистенцією відповідно. Для дослідження протиріч безпосередньо в самій людині необхідне поняття, яке здатне висловити екзистенційно-есенційну обумовленість іiі буття. Таким виявляється поняття «амбівалентність» (від лат. Ambo - «обидва» i лат. Valentia - «сила»), що фіксує в рамках психології одночасні різноспрямовані потяги людини. Екстраполювавши це психологічне поняття в область філософії, ми отримуємо можливість зафіксувати екзистенційноесенційну обумовленість бугтя людини, яке відображається в одночасному різноспрямованому потязі до збереження своєї сугності і до розгортання іï в рамках існування. На цьому етапі роздумів амбівалентність - не просто різновид бінарних відносин, а визначальне і обумовлене екзистенцією явище, яке має в бугті людини своє місце [10].

Схематично бугтя бачиться нам як послідовний розвиток життя. Спочатку бугтя являє собою тотальність життя у всіх іiі можливих проявах, що відображається в конщепті «в-собі» буття. Потім відбувається визначення сугності, коли життя починає усвідомлювати себе і покладати своє бугтя, що виражається в концепті «для-себе» буття. У цей момент з'являється людина як знакова сугність в структурі буття. В результаті формується особлива структура, що знаменує собою власне саме бугтя людини, на якому свідомість прагне розширитися, розвинугися ще інтенсивніше, при цьому сутність прагне зберегти свою тотожність і життя в-собі. У підсумку, буття людини виявляється поміж двох областей: покладанням себе i покладанням світу, тотожністю і розвитком 


\section{Питання психології}

відповідно. Ця динамічна напруга породжує безліч феноменів буття людини.

Амбівалентність як буття, сугність i існування, вводилися i досліджувалися багатьма відомими філософами, кожен з яких вніс внесок у розуміння названих категорій, посприявши їх становленню на протязі розвитку філософської думки.

Серед філософів-екзистенціалістів, які зробили найбільший внесок у позначення специфічних категорій потрібно назвати С. К'єркегора, Ж.-П. Сартра, М. Хайдеггера, К. Ясперса. Очікування небуття перед лицем смерті надає людському існуванню екзистенціальний характер. Так, Сартр включає в небуття не тільки "ніщо", але і безглуздість. Самоствердження людини тим сильніше, чим більше небугтя вона може вмістити в себе.

Серед філософів-постмодерністів особливе місце займають Ж. Батай, Р. Барт, Ж. Бодрійяр, Ж. Дельоз, Ж. Дерріда, Ю. Крістева, Ж. Ліотар. [10]

Юлія Крістєва пояснює амбівалентність як особливий ефект діалогізму. Вона зазначає про існування особливої амбівалентної «поетичної логіки», яка перевершує бінарну логіку. Надалі Ю. Крістєва розширює значення амбівалентності до загального співвідношення практики і Бога, дискурсу та історії, діалогізму i монологізму, логіки взаємовідносності i арістотелівської логіки, синтагми і системи, карнавалу і оповідання, так що в підсумку амбівалентність стає у неї універсальним механізмом взаємного руху протилежностей.

Наразі, здійснюється широкий аналіз форм репрезентації амбівалентності в бутті людини. Так, амбівалентність знаходить своє повне вираження в основних феноменах буття людини. Крім основних феноменів, амбівалентність також обумовлює і мова людини. Область мови також $\epsilon$ сферою амбівалентної невизначеності та неоднорідності, яка випливає 3 самої екзистенції людини. Прагнення людини до самопокладання виражається в iï думках (показує есенцію людини в формі абсурду) і мові (показує екзистенцію людини в формі логіки). Амбівалентність мови виникає 3 співіснування в екзистенції цих двох структур, які демонструють амбівалентне співвідношення сенсів. Звернення до сенсової деконструкції стало домінантним не тільки в філософії поструктуралізму, але і набагато раніше: в рамках аналітичної філософії i філософії абсурду. Вони вибудовують свої тексти і філософію загалом, виходячи 3 прийняття амбівалентності мови, не намагаючись подолати іii.

Н. Котова спробувала систематизувати зв'язок між особистісною амбівалентністю і характеристиками дискурсу, де дискурс визначається як інтегративне діяльніснокомунікативне середовище, яке сприяє системній реалізації ознак, що визначають амбівалентну мовну особистість. Авторка ілюструє особистісну мовну амбівалентність на прикладі давньоримських імператорів, про яких писав у своїй роботі доктор історичних наук, академік А. Ільяхов.

П. Тілліх спробував осмислити амбівалентність 3 позиції відношення іiі до тривоги. В своїй праці «Мужність буги» він виділяє три форми тривоги: тривога долі i смерті, тривога порожнечі і втрати сенсу, тривога провини і засудження. Автор зазначає, що тривога виникає тому, що бугтя людини не тільки дано їй, а й пред'явлено їй як вимога. Людина несе відповідальність за своє бугтя. Вона зобов'язана дати відповідь на питання, що вона $з$ себе зробила, принаймні самій собі. Дана ситуація викликає тривогу, яка у відносних термінах є тривога вини, в абсолютних - тривога самовідторгнення, або самоосуду. У логічних системах думки часто говориться про перетворення можливості в реальність. Але фактично все йде не так просто. Між першим і другим лежить один вирішальний момент. Це - тривога, стан, в якому бугтя усвідомлює можливість свого небуття. Філософ стверджує, що мужність буги - це мужність стверджувати нашу власну розумну природу всупереч всьому тому в нас, що протистоїть нашому єднанню 3 розумною природою самого бугтя. Людина посправжньому стає людиною тільки в момент прийняття рішення [12].

«Амбівалентність» - одне 3 головних понять Михайла Бахтіна, що застосовувалося ним для пояснення карнавального сміху i слова. У традиційному суспільстві, пише він, життя людей розділяється на дві частини: будні і карнавал, що займає до трьох місяців в році. Карнавал - це друге життя народу, організоване на початку сміхом. Це його святкове життя. Опозиція двох способів життя настільки абсолютна, що може визначатися в онтологічних термінах, як «двосвітність». В карнавалі саме життя грає, а гра на час стає самим життям. В цьому специфічна природа карнавалу, особливий рід його бугтя. Карнавальна амбівалентність - щось більше, ніж семантичний ефект, щось більше, ніж 


\section{Питання психології}

діалог або діалектика, вона зачіпає не тільки думку, а й «рід буття» людей [1].

Петер Зима розглядає амбівалентність як рудиментарну, неповноцінну форму діалектики, де бракує третього члена- синтезу. Амбівалентність виробляє шоковий ефект, так як «не піддається ніякому однозначному визначенню і ніякому синтезуючому жесту»).

А. Лобанова у свойй праці «Феномен соціальної мімікрії» використовує поняття «амбівалентність особистості» у позначенні подвійної моралі, як суб'єктивно-оцінний спосіб ставлення окремих людей до дійсності, коли вони, приховуючи свої справжні наміри та ціннісні орієнтації, навмисне вербалізують у комунікації та реалізують у інтеракції вигадані маскувальні словесні коди та соціальні дії 3 метою завоювання довіри до себе. Вона зазначає, що амбівалентність являє собою суперечність між усталеними почуттями до предмета i ситуативними емоціями, що виникають на їх підставі. В загальноприйнятому розумінні амбівалентність свідомості виявляється через наявність у людини двоїстості оцінок і суджень стосовно морально-етичних норм, певних суспільних чи соціальних явищ. За словами авторки, амбівалентність властива тим соціальним суб'єктам, які використовують «мімікріюзахист» для того, щоб вижити в складних для них умовах.

Другий напрям дослідження амбівалентності у філософії було здійснено у розрізі амбівалентності сакрального. Феномен сакрального багато дослідників відносять до однієї з фундаментальних проблем культури.

Класичне визначення амбівалентності сакрального було запропоновано РобертсономСмітом в «Лекціях про релігію семітів» (1889) і передбачало паралельне існування двох форм виключеного $з$ життя індивіда і колективу святого i нечистого, а також можливість взаємного переходу одного в інше. При цьому обидва стани мисляться як "додаткові" якості тих чи інших речей, нейтральних самих по собі. Саме це формулювання було сприйняте французькою соціологією в особі Герца, Дюмезиля, Дюркгейма, Мосса, та інших.

Згодом амбівалентність сакрального отримала теоретичне тлумачення у засновника французької школи соціології Еміля Дюрктейма. Зокрема, він виділяє в житті традиційних суспільств розподіл реальних і ідеальних речей, які уявляють собі люди, на два протилежних класи або роди і позначає їх двома різними термінами, такими як «профанне» $\mathrm{i}$ «сакральне». Їх опозиція - абсолютна і ніяк не зводиться. Дюркгейм вказує на чередування профанного і сакрального періодів часу на прикладі буднів і свят. Він виділяє позитивний $\mathrm{i}$ негативний бік сакрального, де бачить в першому - джерело життя, здоров'я і всіх найкращих людських цінностей, а 3 другого боку - зло і нечисту силу, джерело хаосу, причини смертей і хвороб [11].

Рудольф Отто виділяє відчуття жахливого i чаруючого як базову дихотомію або фундаментальну протилежність, що символізує граничну відкритість існування i являє собою джерело всіх інших дихотомій, саму сутність амбівалентності сакрального. У своій праці «дея священного» Р. Отто стверджує апріорність категорії «святе» стосовно будь-якого релігійного досвіду. Грунтуючись на вченні I. Канта про апріорні форми свідомості, Р. Отто досліджує феномен «святого» (сакрального). Він визначає, що сугність надприродного не вичерпується виключно раціональними предикатами, такими, як Благо, Істина, Воля. Навпаки, ці раціональні моменти, що виступають на передньому плані, співвідносяться й одержують своє головне значення, виходячи 3 «темної глибини» ірраціонального, яке «відкривається нашому почугтю, але недоступне для нашого розуму». Р. Отто стверджує, що сутністю будь-якої релігії $\epsilon$ переживання священного як misterium tremendum etfascinans («містерія жахаюча та чаруюча»). Дослідженню цього амбівалентного психологічного стану він приділяє велике значення й детально описує ступені його розгортання, зокрема, такі, як: власне жах (tremendum), велич (majestas), божественна енергія (energicum), таємниця (mysterium). Підкреслюючи споконвічно ірраціональний характер переживання сакрального, неприступність його для понятійного аналізу, Р. Отто зосереджує свою увагу на його феноменологічнопсихологічному аспекті. Сакральне, як стверджує Р. Отто, - духовне, вічне, трансцендентне, надчуттєве [13].

Р. Скотт Епплбі розглядає амбівалентність сакрального 3 точки зору вибору людини в ситуації конфлікту між релігійним насиллям i релігійним пацифізмом. А Еміль Бенвеніст розділяє сакральне на дві полярності священного, що несугь благо і загибель.

М. Корецька обгрунтовує цілий концепт амбівалентності влади в контексті амбівалентності сакрального. Саме поняття влади, зазначає авторка, двозначне: ще розпочинаючи 3 філософії Ніцше, владу 


\section{Питання психології}

розуміють i як творчий потенціал, i як репресивну машину панування. Філософська концептуалізація влади неоднозначна, оскільки влада, як соціальне явище, має амбівалентний характер. Традиційний спосіб легітимізації влади полягає в iї сакралізації. Проте, із-за того, що сакральне амбівалентне (одночасно пов'язане як з благодаттю так і зі скверним), ті ж характеристики амбівалентності можуть бути притаманні владі.

К. Островська розглядає проблему амбівалентної природи сакрального, що складає стержень концептуального поля концептосфери народної чарівної казки. Вона зазначає, що амбівалентність сакрального зберігає подвійне значення, що актуалізується одночасно через концепти i антиконцепти такі як святий $\mathrm{i}$ грішний, благословення і прокляття [14].

Вже в XXI столітті внесок у розвиток уявлень про амбівалентність внесли $\Phi$. Гиренок і Т. Ойзерман, Є. Шапінська і В. Шапінський, завдяки роботам яких можна простежити становлення феномена амбівалентності в його філософському контексті. Написані в історико-філософській формі роботи T. Ойзермана дозволяють оцінити варіативність "прочитання" феномена амбівалентності, різноманіття народжуваних філософами концептів, організуючих думки в амбівалентному ключі [10].

Вагомий внесок щодо дослідження феномену амбівалентності в філософському бутті людини було здійснено К. Цвітухіною. В своїй праці “Феномен амбівалентності в проекті буття людини" авторка зазначає, що феномен амбівалентності $\epsilon$ антропологічною підставою бугтя людини, який зображується в розриві екзистенціальних i есенціальних потягів людини та виражений у співіснуванні логік що виключають одна одну. Їх подолання позбавляє екзистенцію присутності, а людину - сенсу. Вона виділяє три типи амбівалентності (інтелектуальну, вольову та емоційну), які розкриваються i демонструються 3 найбільшою точністю і ясністю через основні феномени бугтя людини: працю, гру, любов та смерть [10].

У прийнятті амбівалентності закладений імпульс до здійснення такого роду проекту, коли суперечливе міркування може буги визнано адекватним, більш того - єдино вірним. Людина, яка навчилася сприймати буття не як раціональність, а як амбівалентність, побачить, як скоротиться відстань між ним самим і цим буттям. За людиною визнається право бути унікальною $\mathrm{i}$ неповторною одиницею, що представлено в іiі сутності, здатної до розвитку і розширення свого буття шляхом втрати своєї початкової тотожності і визначеності, що виражено в іiі існуванні. Це виявляється можливим тільки завдяки некласичному мисленню, основні принципи якого можугь буги сформульовані наступним чином: необхідність усвідомлення панівних і поляризуючих ідей; пошук різних підходів до явищ; вивільнення з-під жорсткого контролю шаблонного мислення; використання випадку. При цьому підході, що включає всю різноманітність природи людини, яка може бути виражена в іï екзистенційноесенціальній обумовленості, можна побачити за звичним одновалентним світом новий, незвичний і багато в чому шокуючий вимір. Відмова від нав'язаної ідентичності - перший крок на шляху до справжності.

У психологічній науці методологічною $\mathrm{i}$ теоретичною основою дослідження амбівалентності $\epsilon$ : наукові положення психології про розвиток особистісної амбівалентності (К. Абрахам, А. Адлер, Е. Блейлер, М. Клейн, 3. Фрейд, К. Хорні, К. Юнг); особливості розвитку потреби в пізнанні (Ю. Орлов, Л. Фрідман, Г. Щукіна); довіри до себе та самоефективності (А. Бандура, М. Єрусалем, С. Пантілєєв, Т. Скрипкіна, Р. Шварцер); концепції про сутність амбівалентності як властивості атитюдів (М. Занна, С. Томпсен); дослідження в галузі соціальних установок (Д. Узнадзе, Г. Олпорт, М. Сміт, В. Ядов); принцип актуалізації особистісного потенціалу як детермінанти розвитку особистості (К. Роджерс).

Ряд психологів (T. Зелінська, Т. Лук'яненко), виходячи 3 визначення амбівалентності як властивості особистості, розглядають iї трикомпонентну структуру, а саме: мотиваційну, афективно-когнітивну та поведінкову. Амбівалентність особистості властивість, котра виявляється у співіснуванні рівних за потенційністю, взаємоприйнятних, протилежних бажань, почугтів, думок та дій до зовнішнього чи власного, внутрішнього світу, що феноменологічно закріплюється у мотиваційній, афективній та поведінковій сферах вітокультурного бугтя людини [2].

Біхевіорист Б. Скіннер у своій концепції оперантного обумовлення використовує протилежні (тобто амбівалентні) системи та методи для своїх дослідів у камері, а саме систему нагород і покарань і чотири різновиди оперантного обумовлення: позитивне і негативне підкріплення, покарання і гасіння [9].

За Альфредом Адлером, особистість визначається амбівалентним протистоянням 


\section{Питання психології}

емоційних, професійних і суспільних чинників. У своій індивідуальній психології А. Адлер використовує два протилежні терміни: комплекс меншовартості та комплекс зверхності. Він був переконаний, що рушійною силою вчинків людини $є$ особиста вигода (першість), а також соціальний статус (успіх). За його теорією, люди які прагнуть першості, не надто турбуються про інших і зосереджені лише на особистій вигоді, а отже вони психологічно нездорові. Люди, які прагнугь успіху, роблять це для всього людства, не втрачаючи себе, а отже, вони психологічно здорові [9].

У гештальтпсихології використовується амбівалентність у співвідношенні фігури й фону - це притаманна людям схильність сприймати тільки одну частину об'єкта (або передній план), а іншу як тло (або задній план). Маючи на малюнку єдине зображення, людина не може побачити одночасно два малюнка (наприклад вазу і обличчя двох людей).

Карл Роджерс не погоджується ані 3 конщепціями біхевіоризму, ані з психоаналізом. На думку К. Роджерса, людина поводиться певним чином, відповідно до іiі сприйняття ситуації, і тільки сама людина може знати, як вона сприймає дійсність. Роджерс визначив два протилежні стани, які назвав конгруентність неконгруентність. При конгруентності, самосприйняття подібне до Я-ідеального і більше перетинаються між собою. Така людина здатна до самоактуалізації. У людини, що перебуває в стані неконгруентності, самосприйняття відрізняється відрізняється від Я-ідеального і майже не перетинається. Такій людині непросто досягнуги самоактуалізації [9].

Згідно 3 теорією поля Курта Левіна, людина поводиться по-різному, в залежності від сприйняття суперечності між власним Я і тиском оточення [4].

К. Юнг, досліджуючи власну підсвідомість, створив аналітичну психологію. Він вважав життєвим призначенням кожної людини поєднання свідомого і несвідомого для пошуку Істинного Я та назвав цей процес «індивідуацією». Юнг стверджував, що его представляє свідомість людини, колективне несвідоме містить досвід та інформацію, а особисте несвідоме містить спогади усвідомлені та неусвідомлені [9].

На думку Мюррея, кожна потреба людини має важливе значення. Потреби можуть переплітатися, підтримувати або вступати в конфлікт з іншими потребами. За теорією Мюррея, вплив потреб на поведінку людини частково залежить від іï оточення .
Е. Фромм відігравав ключову роль у розвитку гуманістичної психології i досліджував суперечливу природу людини. Згідно з Фроммом, життя людини зводиться до бажання буги частиною природи й водночас відокремитися від неї і люди весь час намагаються втекти від свободи [9].

В. Клименко розглядає амбівалентність як двоїстий психічний стан через призму психологічного маятника почуттів. Вчений показує геометричний образ авторегуляції почугтів у межах перебігу плюса до мінуса через стенічні - астенічні почугтя. Автор наглядно ілюструє катарсис і амбівалентність почуттів при перегляді в театрі комедії та трагедії [3].

Цікавим є дослідження О. Хміляра, який розглядає амбівалентність через призму реверсивності жестів в процесі кодування й декодування повідомлень та розкриває особливості декодування різних амбівалентних жестів і встановлення ступеня довіри до вербальних і психомоторних символів в процесі декодування інформації [8].

Засновник однієї з найуспішніших компаній сучасності «Amazon» Джеф Безос у своїй команді в першу чергу віддає перевагу не тим людям, що ніколи не помиляються, а тим, хто може визнати свою неправоту і змінити думку. Він помітив, що найрозумніші люди постійно переглядають своє розуміння проблеми, яка, як вони вважали, вже була ними вирішена. Вони відкриті для нових точок зору, нових ідей, нової інформації, протиріч і викликів їх власному образу мислення. Ця постійна готовність до прийняття нової інформації йде нога в ногу 3 готовністю визнати, що попередній образ мислення був помилковим або не оптимальним. Іншими словами, щоб бути найрозумнішим, потрібно володіпи інтелектуальною амбівалентністю та гнучкістю розуму. Джеф Безос навіть заохочує вміння завтра знайти ідею, яка буде повністю суперечити вашій сьогоднішній думці. Як показує досвід, люди, які вміють визнавати свої помилки, приймають більш успішні i правильні рішення. Вони розуміють, що допущена помилка $є$ ознакою не легковажності а цікавістю, відкритістю до нових знань і в кінцевому рахунку, розуму.

Висновки та перспективи подальших досліджень.

Феномен амбівалентності обумовлює життя людини і в буденності відчувається як дискомфорт і несправжність, яку вона прагне подолати. Аналіз форм подолання амбівалентності i передбачення неамбівалентного буття, показує, що 


\section{Питання психології}

подолання фальшивості бугтя усуненням 3 нього феномена амбівалентності неможливо.

Включення феномена амбівалентності в буття людини дасть можливість бачити проблему людини в перспективі як вироблення способу збереження-розвитку людського буття i природи людини, де зберігається i вдосконалюється різноманіття реалізації єдності сугності та існування.

Світ амбівалентності виявляється більш живим, а людина, яка вчинила подібну трансформацію - здоровою, стійкою, здатною відчувати повноту і радість життя.

Значною мірою на результат прийняття рішення командиром впливає почугтя амбівалентності. Розглядаючись як неузгодженість та протиріччя декількох одночасно протилежних почуттів, думок, бажань відносно одного і того ж явища чи об'єкта, амбівалентність може як активізувати пізнавальну сферу особистості командира так і здійснювати гальмівний вплив на процес прийняття рішення. Амбівалентність особистості в ситуації невизначеності формується як реакція на зміну різного роду умов, коли відбувається зниження інтенсивності установок, які вже систематизувалися й актуалізується дія локальних адаптивних установок, які $\epsilon$ неусвідомленими i несформованими особистістю. В такий спосіб формуються взаємовиключні протилежності ціннісних орієнтацій особистості, що характеризуються рівною силою та обсягом. Вибір на користь одних чи інших або їх синтез залежить від сформованості особистості, яка дає змогу чинити опір негативним впливам й знаходити вихід у вирішенні внутрішніх суперечностей при прийнятті рішення в умовах невизначеності.

\section{Список використаних джерел}

1. Бахтин М. М. Дополнения и изменения к “Рабле”. Вопр. философии. 1992. № 1. С. 14-15.

2. Зелінська Т.М. Амбівалентність особистості: шлях до гармонії чи душевного болю: навч. посіб. Черкаси: “Сан”, 2005. 200 с.

3. Клименко В.В. Психофізіологічні механізми праксису людини: монографія. Київ : Видавничий Дім «Слово», 2013. $640 \mathrm{c}$.

4. Левин К. Разрешение социальных конфликтов. Санкт-Петербург : Речь, 2000. 408c.

5. Психология мотиваций и эмоций / под ред. Ю.Б. Гиппенрейтер, М.В. Фаликман. Москва.: ЧеРо, МПСИ, Омега-Л, 2006. 752 с.

6. Теплов Б.М. Ум полководца. Избранные труды. Москва, 1985.С. 223-305.

7. Хміляр О.Ф., Черевичний С.В. Психологія прийняття рішення командиром: від амбівалентності до символічної регуляції поведінки. Актуальні проблеми психології. Київ, 2015. Вип. 15. С.224-232.

8. Хміляр О.Ф. Психологія символічної регуляції дій і вчинків особистості: монографія. Київ, 2016. $380 \mathrm{c}$.

9. Хьелл Л., Зиглер Д. Теории личности. 3-е изд. Санкт-Петербург : Питер, 2004. 607 с.

10. Цветухина Е.А. Феномен амбивалентности в бытии человека. // дис. ... канд.филос.наук: Омск, 2014. 214c.

11. Амбівалентність сакрального i словесна культура (Бахтін i Дюркгейм). URL: http://cheloveknauka.com/sakralnoe-kak-ponyatie-i-problema-v-silnoy-programme-kultursotsiologii (дата звернення: 12.03.2019).

12. Соціологія знання E. Дюрктейма i амбівалентність сакрального. URL: https://publications.hse.ru/mirror/pubs/share/folder/tcgiri0164/direct/175447891 (дата звернення: 21.03.2019).

13. The ambivalence of the sacral and the ambivalence of power: from the anthropological conception to the philosophical problem URL: http://magazines.russ.ru/nlo/2015/132/8z.html (дата звернення: 04.03.2019).

14. Амбівалентність базової інтенції філософування Декарта URL: http://dspace.nbuv.gov.ua/bitstream/handle/123456789/43975/2009_1s_7.pdf?sequence=1 (дата звернення: 26.03.2019).

\section{References}

1. Baxty’n M.M. (1992). Dopolneny'ya y' y'zmeneny”ya k "Rable" [Additions and changes to Rabela]. Vopr. fy'losofy'y, 2, 14-15 (Russian).

2. Zelins'ka T.M .(2005). Ambivalentnist' osoby`stosti: shlyax do garmoniyi chy` dushevnogo bolyu [The ambivalence of the individual: the path to harmony or mental pain]. navch. Posib. Cherkasy": "San" (in Ukrainian).

3. Kly`menko V.V. (2013). Psy’xofiziologichni mexanizmy' praksy'su lyudy`ny' [Psychophysiological mechanisms of human praxis].: monografiya. K.: Vy` davny`chy`j Dim «Slovo» (in Ukrainian).

4. Levy`n K. (2000). Razresheny’e socy’al'nыx konfly'ktov [Resolving social conflicts].: Per. s angl. SPb.: Rech' (Russian).

5. Psy`xology`ya moty`vacy’j y’ эmocy`j [Psychology of motivations and emotions]. /pod redakcy'ej Yu.B. Gy’ppenrejter y`M.V. Faly'kman. M.: CheRo, MPSY', Omega-L, 2006 (Russian). 


\section{Питання психології}

6. Teplov B.M. (1985). Um polkovodcza [Mind commander]. M.: Y'zd-vo, 252-343 (Russian).

7. Xmilyar O.F., Cherevy'chny`j S.V. (2015). Psy`xologiya pry jnyattya rishennya komandy’rom: vid ambivalentnosti do sy'mvolichnoyi regulyaciyi povedinky' [Psychology of decision-making by the commander: from ambivalence to symbolic regulation of behavior]. Aktual'ni problemy' psy`xologiyi. Zb.nauk.pr. K.: Insty'tut psy`xologiyi im. G.S. Kostyuka, 5, 224-232 (in Ukrainian).

8. Xmilyar O.F. (2016). Psy`xologiya sy`mvolichnoyi regulyaciyi dij i vchy`nkiv osoby`stosti [Psychology of the symbolic regulation of actions and actions of the individual].: monografiya. K.: TOV «Kontekst Ukrayina» (in Ukrainian).

9. X'ell L., Zy'gler D. (2004). Teory'y' ly’ chnosty' [Personality theory]. 3-e y’zd. SPb.: Py’ter (Russian).

10.Czvetuxy'na E.A. (2014). Fenomen amby'valentnosty' v by'ty'y' cheloveka [The phenomenon of ambivalence in human existence]. dy`s. ... kand.fy'los.n. Omsk (Russian).

11.Ambivalentnist' sakral'nogo i slovesna kul'tura (Baxtin i Dyurkgejm) [Ambivalence of sacred and verbal culture (Bakhtin and Durkheim)]. URL: http://cheloveknauka.com/sakralnoe-kak-ponyatie-i-problema-v-silnoyprogramme-kultursotsiologii (data zvernennya: 12.03.2019) (Russian).

12.Sociologiya znannya E. Dyurkgejma i ambivalentnist' sakral'nogo [Sociology of the knowledge of E. Durkheim and the ambivalence of the sacral]. URL: https://publications.hse.ru/mirror/pubs/share/folder/tcgjri0164/direct/175447891 (data zvernennya: 21.03.2019) (Russian).

13.The ambivalence of the sacral and the ambivalence of power: from the anthropological conception to the philosophical problem URL: http://magazines.russ.ru/nlo/2015/132/8z.html (data zvernennya: 04.03.2019) (Russian).

14.Ambivalentnist' bazovoyi intenciyi filosofuvannya Dekarta [The ambivalence of Descartes's basic intention of philosophizing].URL: http://dspace.nbuv.gov.ua/bitstream/handle/123456789/43975/2009_1s_7.pdf?sequence=1

(data zvernennya: 26.03.2019) (in Ukrainian).

\section{Резюме}

Черевичный С. адъюнкт кафедры общественных наук НУОУ имени Ивана Черняховского

ORCID ID 0000-0001-9691-5261

\section{ВЛИЯНИЕ АМБИВАЛЕНТНОСТИ НА ПРОЦЕСС ПРИНЯТИЯ РЕШЕНИЯ КОМАНДИРОМ: ФИЛОСОФСКО-ПСИХОЛОГИЧЕСКИЙ АСПЕКТ}

В статье представлены современные подходы философско-психологического видения амбивалентности а также проведен анализ ее воздействия на принятия решения командиром в условиях неопределенности.

Ключевые слова: амбивалентность; неопределенность; принятие решения; командир.

\section{Summary}

Cherevychnyi S. adjunct of the Department of Social Sciences of Ivan Chernyakhovsky National Defense University of Ukraine ORCID ID 0000-0001-9691-5261

\section{THE INFLUENCE OF AMBIVALENCE ON THE PROCESS OF COMMANDER'S DECISION-} MAKING: PHILOSOPHICAL AND PSYCHOLOGICAL ASPECTS

Modern approaches to the philosophical and psychological perception of ambivalence were defined and its influence on the process of commander's decision-making in the uncertain environment was analysed in the article.

The relevance of the study. Nowadays, the Ukrainian Army more than ever before needs commanders capable of non-standard, quick thinking, right decision-making in the uncertain environment, and sharp actions in the course of complex military tasks. The sense of ambivalence significantly influences commander's decision.

The aim of the research. To actualise the problem of the commander's decision-making in the uncertain environment, to outline the philosophical and psychological aspects of ambivalence and its influence on the decisionmaking process in the uncertain environment.

The methods of the research. Analytical and review studies of literature.

The sense of ambivalence significantly influences the commander's decision. Ambivalence can be viewed as inconsistency and contradiction of several simultaneously opposite feelings, thoughts, desires concerning one and the same phenomenon or object. It can both activate the cognitive sphere of the commander's personality and have an inhibitory effect on the decision-making process. Ambivalence of the individual in the uncertain environment is formed in response to the change of various conditions, when there is a decrease in the intensity of adjustments, that have already been systematised. The effect of local adaptive adjustments, which have not been acknowledged or formed by the personality, is actualised. Mutually exclusive oppositions of the personality's value orientations, that are characterised by equal strength and volume, are formed. The choice in favor of one or another or their synthesis depends on the formation of the commander's personality. This makes it possible to resist negative influences and find a solution to the internal contradictions in the process of decision-making in the uncertain environment.

Keywords: ambivalence; uncertainty; decision-making; commander. 


\section{Питання психології}

УДК: $159.9:[351.741: 343.102]$

DOI: $10.33099 / 2617-6858-2019-51-1-160-166$

Чухрасва Г. кандидат медичних наук, начальник, Центру психіатричної допомоги та професійного психофізіологічного відбору Держсавна установа «Територіальне медичне об’єднання Міністерства внутрішніх справ України в Харківській області»

\section{ВТІЛЕННЯ ПСИХОЛОГІЧНИХ ОСОБЛИВОСТЕЙ ПРАЦІВНИКА ОПЕРАТИВНО- РОЗШУКОВОЇ ДІЯЛЬНОСТІ В ПРАВОВУ СВІДОМІСТЬ}

Стаття присвячена визначенню основних психологічних особливостей особистості праиівника полічії всіх підрозділів поліиії, $і$ особливо, виокремити ичі аспекти у прачівників з оперативно-розиуковою діяльністю. На основі проведених емпіричних досліджень встановлено, щзо оперативно-розиукова діяльність пов'язана з високою правовою відповідальністю і свідомістю, які межують з високим ризиком водночас.

Ключові слова: правова свідомість; ризик; психологічні особливості; особистість; поліиія.

Постановка проблеми заключається в тому, що питання професійної свідомості та питання професійного ризику не мали можливості практично визначити ці поняття.

Аналіз останніх досліджень і публікацій. Більшість дослідників сходяться на тому, що в прояві професійної правосвідомості працівників поліщії особливе місце займають психологічні чинники. Проблема професійної правової свідомості працівників Національної поліщії України розкривається в дослідженнях В.Л. Васильєва та інших [4].

За даними I. В. Ващенко, коли дії в ситуації ризику працівника поліції спричинюють неочікуваний результат, а негативні наслідки у вирішенні проблем, в певної особистості виникають «особистісні особливості, що визначають схильність до переживання почуття провини» [5].

За К. К. Платоновим «особистість - це людина як носій свідомості» [8; 9].

Н. В. Гришина у своїх працях, пов'язаних 3 дослідженням проблеми особистості, зазначає, що психологічне вивчення особистості взаємопов'язане 3 дослідженням творчих моментів людської діяльності, розуміння яких дасть змогу надати психологічну характеристику й визначення особистості [6].

Мета статті: Метою даного дослідження $є$ визначення основних психологічних особливостей особистості поліщейського 3 оперативно-розшуковою діяльністю, які формують високу правову свідомість, не звертаючи увагу на часті ситуації, як пов'язані з ризиком.

Методи дослідження: Працівникам поліщії, особливо працівникам з оперативнорозшуковою діяльністю, були проведені психодіагностичні обстеження за методиками МБДО, а також емпіричні дослідження, такі як співбесіда, методи нагляду.

Перебуваючи в центрі соціальнополітичних процесів, працівники Національної поліції України в силу специфіки свого соціального положення покликані захищати як права і інтереси громадян відповідно до закону, так і інтереси держави, надавати соціальну допомогу різним категоріям населення. Психологічний аналіз діяльності працівників 3 оперативно-розшуковими функціями діяльності дозволяє зробити висновок про іiі складність, багатовимірність, інтенсивний i експресивний характер. Знання загальних закономірностей діяльності як соціальнопрофесійного феномену сприяє розумінню процесів іiі здійснення та підвищення ефективності.

Специфіка професійного становлення працівників Національної поліщії України, яка полягає в тому, що важливим $є$ їх розвиток не тільки як професіоналів, що володіють професійно важливими особистісними властивостями, але $\mathrm{i}$ як особистостей 3 особливими морально-вольовими, громадянськими якостями, готовністю до правоохоронної діяльності, сформованої професійної правової культурою і правосвідомістю, новоугворенням якого $\epsilon$ професійна правова свідомість [9].

Проблема професійної правової свідомості працівників Національної поліції України розкривається в дослідженнях В.Л. Васильєва та інших [4].

Більшість дослідників сходяться на тому, що в прояві професійної правосвідомості працівників поліції особливе місце займають психологічні чинники. Правова ідеологія по 


\section{Питання психології}

відношенню до психологічної складової правової свідомості не завжди відіграє основну роль. Правова свідомість працівника поліції представлена системою почугтів, установок, поглядів, ціннісних орієнтацій, уявлень та іiі інших складових.

Вивченням правосвідомості працівника поліції займається правова психологія, а саме: вивчає закономірності розвитку i функціонування правосвідомості та правослухняної поведінки людини, змін цієї поведінки у зв'язку з соціально-економічними реформуваннями в структурі суспільства [7].

Сформованість професійної правової свідомості $\epsilon$ основним чинником серед чинників свідомості працівника 3 оперативнорозшуковими функціями діяльності. Служба в поліції є однією з самих складних в силу різних причин, тим паче, вона залишається низько оплачуваною i на сьогоднішній день. Цей чинник $є$ негативним в першу чергу тим, що не дозволяє залучити на службу високоінтелектуальну та перспективну частину молоді, яка намагається знайти себе на інших ділянках діяльності. Тим не менше професія потребує від людини великої віддачі, так як відрізняється непомірно великою фізичною, емоційною, моральною напругою, ненормованим робочим днем, ризиком для життя та здоров'я [3].

Службова діяльність осіб рядового та начальницького складу пов'язана 3 підвищеною відповідальністю працівників за свої дії. Під час виконання службового обов'язку працівникам нерідко доводиться знаходитися в ситуаціях з непередбачуваним результатом, які характеризуються недостатньою визначеністю рольових функцій, психічними і фізичними перевантаженнями, необхідністю спілкуватися 3 найрізноманітнішим контингентом громадян $\mathrm{i}$ вимагає від працівника рішучих дій і здатності піти на ризик.

Найчастіше працівників поліції провадиться в напружених умовах, конфліктних ситуаціях, небезпечних для життя обставинах.

Якщо працівник спецпідрозділу поліції володіє емоційно-вольовою

стійкістю, він легше долає психологічні наслідки невдач і зривів [1].

Зрозуміло, що більше позитивних («ділових») якостей має людина, то швидше вона буде досягати будь-яких цілей. Тому розвиток цих якостей повинен бути пріоритетним у розвитку особистості працівника поліції.

Особистість - це системна якість, яку здобуває суб'єкт (індивід) у системі діяльностей, що здійснюють його життя в суспільстві й у системі об’єктивних відносин суспільства [2].

За К. К. Платоновим «особистість - це людина як носій свідомості» [8;9].

Н. В. Гришина у своїх працях, пов'язаних 3 дослідженням проблеми особистості, зазначає, що психологічне вивчення особистості взаємопов'язане 3 дослідженням творчих моментів людської діяльності, розуміння яких дасть змогу надати психологічну характеристику й визначення особистості [6].

Відповідно до «Закону про Національну поліцію України» ст. 29 «Основні принципи служби в Національній поліції України» одними 3 основних принципів працівника поліції $\epsilon$ професіоналізм, компетентність, ініціативність відданість справі, а також особиста відповідальність за свої власні дії і за незаконність або бездіяльність.

Тому в екстремальних ситуаціях, коли обмаль часу для прийняття рішень та дій рівень професіоналізму, компетентності є запорукою позитивного результату в випадках ризику.

Ризик - це поняття, яке залежить від емоційної стійкості, від особистісних особливостей особистості, від його інтелектуальних здібностей та деяких інших. Динамічні особливості психічної діяльності залежать від емоції і від волі. Тому вони визначаються відношенням емоційних i вольових особливостей. Ризик може бути i необхідним, і невиправданим [8].

Розумна схильність до ризику - це швидкість реакції, вміння орієнтуватися в складній обстановці.

Ризик - ситуативна характеристика діяльності, що полягає в невизначеності іiі результату i можливих несприятливих наслідках в разі неуспіху [9].

Ризик характеризується можливістю вибору між менш або більш небезпечними для працівника поліції варіантами поводження, але розрізняються за ступенем їхньої ефективності 3 погляду досягнення результатів діяльності.

Часто ризиковане поводження дає змогу досягти мети діяльності швидше й 3 мінімальними втратами. Самі види ризику різноманітні: ризик зриву рішення службового завдання, ризик одержання стягнення, ризик 


\section{Питання психології}

звільнення 3 посади, ризик одержання фізичного ушкодження, ризик для свого життя, ризик для свого авторитету й морального престижу й ін. [9].

За даними I. В. Ващенко, коли дії в ситуації ризику працівника поліції спричинюють неочікуваний результат, а негативні наслідки у вирішенні проблем, в певної особистості виникають «особистісні особливості, що визначають схильність до переживання почугтя провини» [5].

Спірним було питання, чи дасть змогу методика виявити особистісні властивості індивіда або особливості його стану. Сьогодні більшість дослідників уважає, що особливості стану значною мірою визначаються індивідуальним типом реагування й виявляються посиленням, загостренням або ослабленням особистісних якостей [10].

У сучасних умовах від працівників поліції вимагається: посилення професійного потенціалу, забезпечення психологічної готовності до екстремальних ситуацій та уміння своєчасно реагувати на ситуацію, захищаючи правопорядок. $\mathrm{y}$ період проведення реформування, яке торкається всієї системи правопорядку МВC психологічне навантаження на працівників системи ще більше зростає.

3 огляду на професійну діяльність працівників 3 оперативно-розшуковими функціями, їх служба є найбільш небезпечною та складною. Ці працівники повинні мати високу мотивацію досягнень, впевненість у собі, позитивну самооцінку, зокрема рішучість, яка близька схильності до ризику, а значить i високу ступінь адаптації.

Функція адаптації визначається переважно двома чинниками, а саме: прагненням особистості до самореалізації, до досягнення мети й задоволення потреб у протидії Діючим чинникам середовища, що обмежують самореалізацію особистості, а також тенденцію до підвищеного самоконтролю 3 відмовою від досягнення потреб заради збереження конкрентних відносин 3 оточенням. Перевага показників стенічної самореалізації може спричинювати порушення адаптації за соціальноповедінковим типом насамперед, гіпостенічний стан означає відмову від самореалізації й перевагу соціального тиску i тиску середовища на особистість, що сприяє виникненню невротичного патерну дезадаптації. В разі перенапруження тих й інших тенденцій відбувається взаємне їхнє зниження. Блокованими виявляються невротичний і поведінковий відвідні канали, які відреагували в емоційному регістрі, що приводить до дезадаптації.

Працівникам поліції, особливо працівникам 3 оперативно-розшуковою діяльністю, були проведені психодіагностичні обстеження за методиками МБДО, а також емпіричні дослідження, такі як співбесіда, методи нагляду. Нами були отримані наступні результати 3 данними психологічних особливостей данних працівників поліції. Прагнення до лідерства, суперництва, домінування, подолання перешкод, самостійності в прийнятті рішень і дій. Високий рівень пошукової активності. Прагнення до незалежності, вільної поведінки, безпосередності. В умовах емоційного залучення - чітко виражені протилежні емоції. Мотив досягнення успіху пов'язаний $з$ волею до реалізації сильних бажань; схильність до ризику. Висловлення й дії не можугь випереджати планомірну і послідовну продуманість учинків. Можна 3 впевненістю зазначити, що така риса характеру, як схильність до ризику, особливо притаманна працівникам поліції спеціальних оперативних підрозділів. Для працівників пспеціальних підрозділів поліщії більш характерні: схильність до ризику, здатність і схильність до високої активності, невимушеності в спілкуванні, ініціативності, ризику. Прагнення буги в центрі уваги, максимально інформованим. Енергійність, висока працездатність, витривалість, організаційні здатності. їхнє лідерство зазвичай сприймається оточуючими як природне явище. Добре розвинені навички спілкування.

Особи рядового та начальницького складу підрозділу БПОП (колишнього СПШР) - більш рішучі, життерадісні, владні, мають егоїстичний тип особистості, у них переважають: соціальна пристосованість, широке коло інтересів, сценічність, багата уява, наполегливість, упертість, виражене прагнення до емоційного залучення, сензи- тивність до критичних зауважень i зовнішніх впливів, схильність до перебільшення своїх можливостей, невимушеність у спілкуванні, здатність висловлювати свою думку, готовність поділитися враженнями.

Ці специфічні особливості професійної діяльності роблять значний вплив на особистісні характеристики іï представників і 


\section{Питання психології}

можуть призводити до негативних соціальнопсихологічних наслідків [11].

Оперативно-службові завдання, що стоять, наприклад, перед працівниками кримінальних та слідчих підрозділів, вимагають прояву специфічних професійних якостей, найважливішими 3 яких є здатність до адекватної самооцінки. У працівників поліції, представників цих двох професійних груп, мають бути сформовані деякі соціальнопрофесійні якості, що дозволяють їм успішно виконувати складні завдання, взаємодіяти 3 іншими людьми. У такому розумінні соціально-професійні групи - це сукупність фахівців, професійна діяльність яких пов'язана iз спілкуванням i взаємодією 3 людьми. Специфічність соціально-професійних груп працівників Національної поліції України являє собою особистісні якості, які проявляються в адекватності рішення (стандартних та які вимагають творчого підходу). Професійна ідентифікація особистості працівника Національної поліції України залежить, в першу чергу, від професійної самосвідомості як системи особистісних якостей, які демонструються в професійній діяльності всьому суспільству. Відповідність професійної ролі і особливостей особистості працівників $\epsilon$ структурнофункціональною відповідністю, на підставі якої функціонує професійно-особистісна модель працівника в громадській думці. Деформація структурно-функціональної відповідності професійної ролі працівників Національної поліції України і їх особистісних проявів викликає суспільну потребу в корекції відповідності ролі і поведінки службовця [4].

Так, у процесі вирішення оперативнорозшукових завдань оперуповноважений працівник та слідчий часто змушений впливати специфічно та психологічно на різні категорії громадян, зокрема, для отримання оперативної інформації в процесі спілкування 3 конфіденційними джерелами, в ході опитувань i допитів, що висуває дуже високі i різносторонні вимоги до особистості працівника, а наявність знань і вмінь у сфері комунікативної взаємодії та вирішення конфліктних ситуацій при здійсненні профілактичних завдань відіграють величезну роль. Вивчення особистісних особливостей працівників Національної поліції України представників різних соціально-професійних груп залежно від соціально-демографічних i професійних характеристик $€$ головною складовою для реалізації психологічного потенціалу особистості працівників i соціально-психологічного супроводу їх діяльності, особливо для працівників Національної поліції України 3 оперативнорозшуковими функціями діяльності[12].

Якщо усвідомлення особистістю свого зв'язку з групою своєї спільноти відіграє роль спонукання і емоційно забарвлене, то загальні елементи у змісті свідомості членів групи значною мірою регулюють їх спільну діяльність. Отже, якщо на рівні самооцінок не забезпечується єдиної подібності, цілісності, то не виникає передумов для формування професійної групової свідомості. Залежність станів групової свідомості від рівня розвитку групи безсумнівна[9].

У разі великої кількості міжособистісних контактів у різних сферах, $\epsilon$ імовірність нетривалого, поверхневого спілкування. Здатність переносити неминучі труднощі в спілкуванні без реакцій тривоги і пригніченості. Виражені схильність до пригод, хоробрість, наполегливість, упертість, заповзятливість, прагнення до подолання перешкод, самоствердження; постійне прагнення до зовнішньої збудливої ситуації. Властива демонстрація мужнього стилю життя, сили, витривалості, зневаги до дріб'язків, наполегливості. $\mathrm{C}$ значущим соціальний престиж. Не виключена підвищена чутливість стосовно дійсних або уявних несправедливоетей. Характерні життєрадісність, рішучість, упевненість у собі, владність, екстравертованість, честолюбство. Прагнення керуватися твердим наміром буги кращим, розумнішим від інших, лідирувати в груповій діяльності. Для задоволення честолюбства необхідні реальні досягнення й результати, що підтверджують престиж i значущість.

У широкому плані поняттям професійної свідомості можна визначити всі ті прояви свідомості особистості, які пов'язані 3 ii професійною діяльністю. Вони визначаються: місцем i значенням даної професії в професійній структурі суспільства; ставленням особистості до професії, іï представникам і до себе як професіонала; професійними ідеалами. Більшість авторів вкладають в це поняття усвідомлення людиною своєї приналежності до певної професійної групи та трактують його як вибіркову діяльність самосвідомості особистості, підпорядковану завданню самовизначення; усвідомлення себе як суб’єкта 


\section{Питання психології}

професійної діяльності. У цьому випадку стають очевидними дві головні особливості суб'єкта даної діяльності. По-перше, він набуває рис полісуб'єктності, знаходить статус колективного (групового) суб'єкта. По-друге, суб'єкт стає при цьому не тільки «множинним» i «розподіленим», але i організованим. Завдяки рефлексивним властивостям і процесам відбувається не тільки диференціація - виділення індивідуального суб'єкта («Я сам»), а й стає можливою їх подальша інтеграція в рамках колективного суб’єкта («Ми разом») [13].

Ми розуміємо під груповою професійною свідомістю працівника поліції усвідомлення себе в системі своєї професійної діяльності, в системі професійного спілкування та взаємодії з населенням, в системі власної особистості.

Висновки.

Захист інтересів держави та інтересів громадян, які виконують працівники поліції, особливо працівники 3 оперативнорозшуковою діяльністю, пов'язаний з високою правовою свідомістю і відповідальністю, які в першу чергу формуються на основі основних психологічних особливостей особистості поліщейського. При проведенних психологічних обстеженнях працівникам поліції спеціальних підрозділів і працівників 3 оперативно-розшуковою діяльністю можно зазначити, що такимми спільними рисами $\epsilon$ Прагнення до лідерства, суперництва, домінування, подолання перешкод, самостійності в прийнятті рішень і дій.
Високий рівень пошукової активності. прагнення до незалежності, вільної поведінки, безпосередності. В умовах емоційного залучення - чітко виражені протилежні емоції. Мотив досягнення успіху пов'язаний 3 волею до реалізації сильних бажань; схильність до ризику. Висловлення й дії не можугь випереджати планомірну і послідовну продуманість учинків. Можна 3 впевненістю зазначити, що така риса характеру, як схильність до ризику, особливо притаманна працівникам поліції спеціальних оперативних підрозділів. Для працівників пспеціальних підрозділів поліції більш характерні: схильність до ризику, здатність і схильність до високої активності, невимушеності в спілкуванні, ініціативності, ризику. Прагнення буги в центрі уваги, максимально інформованим. Енергійність, висока працездатність, витривалість, організаційні здатності. ӥхне лідерство зазвичай сприймається оточуючими як природне явище. Добре розвинені навички спілкування.

Оперативно-службові завдання, що стоять, наприклад, перед працівниками кримінальних та слідчих підрозділів, вимагають прояву специфічних професійних якостей, найважливішими з яких є здатність до адекватної самооцінки. У працівників поліції, представників цих двох професійних груп, мають бути сформовані деякі соціальнопрофесійні якості, що дозволяють їм успішно виконувати складні завдання, взаємодіяти 3 іншими людьми.

\section{Список використаних джерел}

1. Бандурка А. М. Профессионализм и лидерство : учеб. пособ. / А. М. Бандурка, С. П. Бочарова, Е. В. Землянская. - Харьков : Титул, 2006. - 578 с.

2. Барко В. И. Профессиографическое описание основных видов деятельности в ОВД Украины. К.: КНУВД, ГП. Типография МВД, 2007.

3. Берестовой С.Г. Социально-психологические представления о качестве жизни в профессиональном пространстве ОВД. 19.00.05 - Авторефер. дис. канд. псих. наук, Кострома - 2006.

4. Васильев В.Л. Системный профессиографический подход к подбору и расстановке кадров правоохранительных органов // Материалы междунар. научн. практ. конф. СПб., 1995. - С. 65-70

5. Ващенко I.В. jarina 62@ ravifer. ru . Проблеми сучасної психологіï. 2016. Випуск 34.

6. Гришина Н.В. Психологія конфлікту. - 2-е вид., - СПб.: Пітер, 2008.

7. Мерищук Л.В. Психологические основы формирования профессионально значимых качеств; Дис. Дра психол. Наук / В.Л. Мерищук. Л., 1982.-351 с.

8. Платонов К.К. Необходимые уточнения (о методических проблемах профессионального отбора в профессиональной ориентации) // Социалистический труд, N 10, 1970, С. 94 - 100.

9. Платонов К.К. Система психологии и теория отражения /К.К. Платонов.-М.: Наука, 1982. - 310с.

10.Слєдков Е.В. Боєва психічна травма (клініко-патогенетична динаміка, діагностика, лікувальнореабілітаційні принципи): Автореферат докт. мед. наук. -СПб.: 1997. - 48 с.

11.Чухраєва Г.В. Психологічні особливості схильності до розвитку професійної деформації особистості / Г.В. Чухраєва // Науковий Вісник Миколаївського Національного університету ім.. В.О. Сухомлинського. 2014. -№2.12 (103) - С. 235-238. 


\section{Питання психології}

12.Чухраєва Г.В. Соціально-психологічні особливості якості життя працівників ОВС / Г.В. Чухраєва // Вісник Національного університету оборони України. Харків - 2014. -№2 - С. 313-318.

13.Шестов Л. Киркегард и экзистенциальная философия. М., 1992.

\section{References}

1. Bandurka A.M. Professionalism i liderstvo: echebn. posob. / A.M. Bandurka, S. P. Bocharova, E.V.Zemlianskaia. - Kharkiv: Title, 2006. - 578 s.

2. Barko. V.I. Professiograficheskoe opisanie osnovnykh vidov deiatelnosti v OVD Ukraine. K.: KNUVD, Tipografiia MVD, 2007.

3. Berestovoi S.G. Socialno-psychologicheskie predstavleniia o kachestve zhizni v professionalnom prostranstve OVD. 19.00.05 - Avtorefer. dis. kand. psikh. nauk, Kostroma - 2006.

4. Vasilev V.L. Sistemnyy professiograficheskiy podkhod $\mathrm{k}$ podboru $\mathrm{I}$ rasstanovke kadrov pravookhranitelnykh organov // Materials mezhdunar.nauch. prakt. konf. SPB., 1995. - S. 65-70

5. Gryshyna N.V. Psykhologiia konfliktu. -2 is a e kind., - SPB.: Piter, 2008.

6. Meryshchuk L.V. Psychologicheskie osnovy formirovaniia professionalno znachimykh kachestv; diss. Dokt. Psikhol. nauk / Meryshchuk V.L., 1982.-351 s.

7. Plato of K.K. Necessary clarifications (about the methodical problems of professional selection in a professional orientation) // are Socialistic labour, N 10, 1970, S. 94 - 100.

8. Platonov K.K. Neobkhodimye utochneniia (o metodicheskikh problemakh professionalnogo otbora $\mathrm{v}$ professionalnoi orientatsiyi/K.K. Platonov - M.: Nauk, 1982.-310 s.

9. Sliedkov E.V. Boieva travma (Kliniko-patogenetychna dunamika, diagnostyka, Likuvalno-reabilitatsiini pryntsypy): Avtoreferat dokt. med. Nauk. - SPB.: 1997. - 48 s.

10. Chukhraeva G.V. Psychologichni osoblivosti skhylnosti do rozvytku professiinoi deformazii osobustosti / G.V. Chukhraeva // Naukovyi Visnyk Mykolaivskoho Nationalnoho universitetu im. V.O. Sukhomlinskogo - 2014. №2.12 (103) - S. 235-238.

11. Chukhraeva G.V. Sozialno-psychologichni osoblivosti yakosti zhuttya prazivnykiv OVS / G.V. Chukhraeva // Visnyk Nazionalnogo universitetu oborony Ukrayiny. Kharkiv - 2014. -№2 - S. 313-318.

12. Shestov L. Kirkergard I ekzistentsialnaya filosofiya. M., 1992.

\section{Резюме}

Чухраева А. кандидат медииинских наук, начальник, Центр психиатрической помощи и профессионального психофизиологического отбора Государственное учрељждение «Территориальное медиинское управление Министерства внутренних дел Украины в Харьковской области»

ВНЕДРЕНИЕ ПСИХОЛОГИЧЕСКИХ ОСОБЕННОСТЕЙ СОТРУ ДНИКОВ ОПЕРАТИВНОРОЗЫСКНОЙ ДЕЯТЕЛЬНОСТИ В ПРАВОВУЮ СОЗНАТЕЛЬНОСТЬ

Статья посвящена определению основных психологических особенностей сотрудника полици всех подразделений полищии, а особенно, выделить эти аспекты у сотрудников с оперативно-розыскной деятельностью. На основании проведенных эмпирических исследований определено, что оперативнорозыскная деятельность связана с высокою правовою ответственностью и сознательностью, которые граничат с высоким риском одновременно.

Ключевые слова: правовая сознательность; риск; психологические особенности; личность; полиция.

\section{Summary \\ Chuhraeva G. candidate of medical sciences, Chief, Center of psychiatric help and professional psikhofiziologickal selection Public institution the «Territorial medical association of Ministry of internal affairs of Ukraine in the Kharkiv area»}

\section{EMBODIMENT OF PSYCHOLOGICAL FEATURES OF WORKER OF OPERATIONAL} SEARCH ACTIVITY IN LEGAL CONSCIOUSNESS

Introduction The article is sanctified to determination of basic psychological features of personality of worker of police of all subdivisions of police, and especially, to distinguish these aspects for workers with operational search activity. It is set on the basis of the conducted empiric researches, that operational search activity is related to high legal responsibility and consciousness, that abut upon a high risk at the same time.

Purpose Aim of this research is determination of basic psychological features of personality of policeman with operational search activity, that form high legal consciousness, not paying attention to frequent situations, as related to the risk. 


\section{Питання психології}

Methods To Workers of police, especially to the workers with operational search activity, psihodiagnostik inspections were conducted after methodologies of $M B D O$, and also empiric researches, such as interview, methods of supervision.

Originality a scientific novelty consists in that problem of professional consciousness and risk considered not only from scientific position, and in connection with the psychological features of workers of police, that it is possible to define by means of psihodiagnostikal inspection.

Conclusion. Defence of interests of the state and interests of citizens, that execute workers of police, especially workers with operational search activity, related to high legal consciousness and responsibility, that is first of all formed on the basis of basic psychological features of personality of policeman. At проведенних psychological inspections to the workers of police of the special subdivisions and workers with operational search activity of it is possible to mark that такимии general lines are Aspiring to leadership, rivalry, prevailing, overcoming of obstacles, independence in making decision and actions. High level of searching activity. aspiring is to independence, free behavior, spontaneity. In the conditions of the emotional bringing in - opposite emotions are clearly expressed. Reason of achievement of success is related to will to realization of strong desires; propensity is to the risk. An utterance and actions can not pass ahead systematic and successive carefully thought out of acts. It is possible with a confidence to mark that such character trait, as propensity to the risk, especially inherent to the workers of police of the special operative subdivisions. For the workers of spezial subdivisions of police more characteristic: propensity to the risk, capacity and inclination for high activity, to the ease in a commonunication, initiativeness, risk. Aspiration to be in highlight, maximally informed. Energeticness, high capacity, endurance, organizational capabilities. their leadership is usually perceived by surrounding as the natural phenomenon. Well — developed skills of commonunication.

Operatively-official tasks that stand for example, before the workers of criminal and inquisitional subdivisions, require the display of specific professional internalss major from that is a capacity for an adequate self-appraisal. For the workers of police, these representatives of two professional groups, some socialprofessional internalss, that allow to them successfully to execute difficult tasks, co-operate with other people, must be formed.

Key word: legal consciousness; risk; psychological features; personality; police. 